5. Eizenshtein, S. (2018). Vertikalnyi montazh [Vertical installation], [online] Available at:〈https://royallib.com/read/eyzenshteyn_sergey/vertikalniy_montag.html\#0> [Accessed 10 July 2018].

6. Efimova, N. (2005). Khudozhestvenno-esteticheskii analiz zvukovogo efirnogo prostranstva teleradioveshchaniya [Artistic and aesthetic analysis of the sound air space of broadcasting]. D.Ed. Institute of Advanced Training for Television and Radio Broadcasting Workers.

7. Ignatov, P. (2006). Evolyutsiya sredstv khudozhestvennoi vyrazitel'nosti v tvorchestve zvukorezhissera [Evolution of means of artistic expressiveness in the work of the sound engineer]. D.Ed. St. Petersburg Humanitarian Institute of Trade Unions.

8. Ovsiannikova-Trel, O. (2015). Kinomuzyka iak kulturnyi fenomen suchasnosti [Film music as a cultural phenomenon of our time]. Mizhnarodnyi visnyk: filolohiia, kulturolohiia, muzykoznavstvo, issue 2(5), pp. 163-168.

9. Vereikin, S. (2018). Istoriya kino: rannie gody [History of cinematography: early years], [online] Available at:<http://media-shoot.ru/publ/34-1-0-151> [Accessed 14 July 2018].

(С) Хренов Д. О., 2018

Стаття надійшла до редакиії: 24.09.2018

УДК 688.741/.742:792.051(477)"04/14"

\author{
Юдова-Романова Катерина Володимирівна, \\ кандидат мистеитвознавства, дочент, \\ Київський начіональний університет культури, \\ вул. С. Коновальия,36, Київ, Украӥна, 01133, \\ https://orcid.org/0000-0003-2665-390X, \\ iudovakateryna@gmail.com
}

\title{
ПРОСТОРОВО-ТЕХНІЧНЕ ЗАБЕЗПЕЧЕННЯ УКРАЇНСЬКОГО ТЕАТРУ ЕПОХИ СЕРЕДНЬОВІЧЧЯ
}

Мета дослідження - 3'ясувати особливості сценічного дизайну українського театру та його просторово-технічне забезпечення в епоху Середньовіччя. Основну увагу в історії середньовічного театру автор зосереджує саме на діяльності мандрівних середньовічних артистів та на художньо-постановочних особливостях організації церковного театру. Для досягнення поставленої мети було застосовано наступні методи: критичного аналізу опрацювання наукової літератури 3 історії театрального мистецтва, архітектури та сценічного дизайну 3 метою виокремлення інформації щодо теми дослідження «Дизайн театральної сцени: генезис, історична еволюція, сучасні тенденції»; мистецтвознавчого аналізу - для визначення залежності художності сценічної постановки від ії просторовотехнічного забезпечення; синтезу - для поєднання різних характеристик просторовотехнічного забезпечення українського театру епохи Середньовіччя як складової в еволюції дизайну сцени; індукційний - для вивчення хоч і фрагментарних, але типових прикладів просторово-технічного забезпечення вистав скоморохів та постановок літургійної драми; гіпотетичний, системний та узагальнюючий підходи - для висування на основі наукового припущення про значення в еволюції дизайну сцени мандрівного способу організації діяльності середньовічних професійних акторів та архітектури культових споруд, де зародилась середньовічна літургійна драма Наукова новизна даної публікації полягає в тому, що вперше виконано системний мистецтвознавчий аналіз поступу просторовотехнічного забезпечення вистав українського середньовічного театру в контексті загальноєвропейських процесів. Зокрема, у відповідному художньо-постановочному ключі висвітлено діяльність середньовічних мандрівних артистів та вистави церковного театру. Висновки. У результаті проведеної наукової розвідки авторка стверджує: мандрівний спосіб 
ISSN 2410-1176 (Print) Вісник КНУКіМ. Серія Мистецтвознавство. Вип. 39. ISSN 2616-4183 (Online)

життя середньовічних артистів спонукав до широкого використання ними мобільних способів облаштування публічного простору для показу вистав; особливості архітектури церкви, де показувались вистави середньовічної літургійної драми, вплинули на сучасний умовний тридільний поділ сценічного простору на нижню, основну та верхню сцени; церковний театр вплинув на розвиток дизайну сцени засобами художньо-декораційного оформлення, освітлення та іншої постановочної техніки, а також костюмування.

Ключові слова: дизайн сценічного простору; технічні засоби оздоблення; середньовічні мандрівні актори; церковний театр; літургійна драма.

Юдова-Романова Екатерина Владимировна, кандидат искусствоведения, доцент, Киевский национальньій университет культуры и искусств, ул. Е. Коновальиа,36, Киев, Украина средневековья

Пространственно-техническое обеспечение украинского театра эпохи

Цель исследования - выяснить особенности сценического дизайна украинского театра и его пространственно-техническое обеспечение в эпоху Средневековья. Основное внимание в истории средневекового театра автор сосредоточивает именно на деятельности странствующих средневековых артистов и на художественно-постановочных особенностях организации церковного театра. Для достижения поставленной цели были использованы следующие методы: критического анализа - разработка научной литературы по истории театрального искусства, архитектуры и сценического дизайна с целью выделения информации на тему исследования «Дизайн театральной сцены: генезис, историческая эволюция, современные тенденции»; искусствоведческого анализа - для определения зависимости художественности сценической постановки от еe пространственнотехнического обеспечения; синтеза - для сочетания различных характеристик пространственно-технического обеспечения украинского театра эпохи Средневековья как составляющей в эволюции дизайна сцены; индукционный - для изучения хоть и фрагментарных, но типичных примеров пространственно-технического обеспечения спектаклей скоморохов и постановок литургической драмы; гипотетический, системный и обобщающий подходы - для выдвижения на основе научного предположения о значении в эволюции дизайна сцены странствующего способа организации деятельности средневековых профессиональных актеров и архитектуры культовых сооружений, где зародилась средневековая литургическая драма. Научная новизна данной публикации заключается в том, что впервые выполнено системный искусствоведческий анализ развития пространственно-технического обеспечения спектаклей украинского средневекового театра в контексте общеевропейских процессов. В частности, в соответствующем художественнопостановочном ключе отражена деятельность средневековых странствующих артистов и спектакли церковного театра. Выводы. В результате проведенной научной разведки автор утверждает: странствующий образ жизни средневековых артистов привел к широкому использованию ими мобильных способов обустройства публичного пространства для показа спектаклей; особенности архитектуры церкви, где показывались спектакли средневековой литургической драмы, повлияли на современное условное триделимое разделение сценического пространства на нижнюю, основную и верхнюю сцены; церковный театр повлиял на развитие дизайна сцены средствами художественно-декорационного оформления, освещения и другой постановочной техники, а также костюмирования.

Ключевые слова: дизайн сценического пространства; технические средства отделки; средневековые бродячие актеры; церковный театр; литургическая драма.

Yudova-Romanova Kateryna, PhD in Art Criticism, Associate Professor, Kyiv National University of Culture and Arts, 36, Y. Konovaltsia St, Kyiv, Ukraine

Spatial-technical support of the Ukrainian theater in the Middle Ages

The purpose of the research is to find out the peculiarities of the stage design of the Ukrainian theatre and its spatial and technical support in the Middle Ages. The author concentrates 
the main attention in the history of the medieval theatre on the activities of wandering medieval artists and on the artistic and production features of the church theatre organization. To achieve this goal, the following methods were used: critical analysis - the development of scientific literature on the history of the theatrical art, architecture and stage design in order to highlight information on the research topic "Theatrical scene design: genesis, historical evolution, current trends"; art history analysis - to determine the dependence of the stage production artistic form on its spatial and technical support; synthesis - to combine various characteristics of the spatial and technical support of the Ukrainian theatre of the Middle Ages as a component in the evolution of stage design; induction - to study, though fragmentary, but typical examples of the spatial-technical support of the buffoon and liturgical drama performances; hypothetical, systemic and generalizing approaches - on the scientific hypothesis basis putting forward the significance of a traveling way of activities organisation of medieval professional actors and the architecture of religious buildings holding the medieval liturgical drama for a scene design evolution. The scientific novelty of this publication is for the first time there was carried out a systematic art history analysis of the spatial and technical support development of the Ukrainian medieval theater performances in the context of the common European processes. In particular, the article looks into the activity of medieval wandering artists and the church theater performances from the corresponding artistic and staging point of view. Findings. As a result of the conducted scientific research, the author states: the wandering way of life of the medieval artists caused their wide use of mobile ways of arranging public space for showing performances; the particular the church architecture, where the performances of medieval liturgical drama were shown, influenced on the modern conditional threefold division of the stage space into the lower, main and upper scenes; Church theatre influence on the development of stage design by means of artistic decoration, lighting and other staging techniques, as well as costumes.

Key words: stage space design; technical means of design; medieval roving actors; church theatre; liturgical drama.

Вступ. Загальновідомо, що театральне мистецтво виникло з релігійних містерій, шляхом розподілу учасників на діючих осіб та глядачів. При цьому дія відбувалась у певному архітектурно сформованому просторі, де головним був сценічний майданчик сцена, - простір якого художньо оздоблювався згідно зі змістом та жанром сценічної дії. Закономірно, що при цьому оздоблення сцени, іiї дизайн (або сценографія) зазнавали змін у відповідності до жанрово-змістового різноманіття сценічних постановок та історичного контексту. Саме аналіз цього аспекту сценічного мистецтва невипадково став предметом наукових досліджень упродовж усього часу існування театру.

Аналіз останніх досліджень і публікацій. Одним з перших, хто досліджував зв’язок об'єктивно-зовнішніх, матеріальних обставин сценічної, зокрема, театральної творчості, організаційно-технічні, виробничі, художньо-постановочні іiі умови був Г. Лессінг (1936). В. Базанов (2005) зосереджував свої дослідження у напрямку вивчення естетичних функцій театральної техніки, що визначає пластичний стиль вистави, історії та сучасності архітектури театральних приміщень, технології сцени, організації роботи художньо-постановочної частини театрів. Л. М. Михайлов (2007) вузькою сферою своїх мистецтвознавчих досліджень обрав технічні засоби оформлення саме сучасного естрадного видовища. Проблеми впливу світла на художнє рішення вистави, зокрема, вивчались Н. П. Ізвековим. Дослідженню поетики театру, зокрема, поетиці слов'янського театру бароко Польщі, України та Росії, розкриттю та визначенню іï основних рис присвячено монографію Л. А. Софронової (1981). М. А. Френкель (1987) як сценограф-практик розглядав поетику сценічного простору крізь призму втілення на сцені пластичного художнього образу вистави, на який відповідним чином впливає і архітектурно-сценічний простір постановки, і наявна у ньому техніка. Львівський архітектор В.І. Проскуряков (2001) предметно, системно та глибоко дослідив архітектуру українського театру в історичному та функціональному аспектах. Г. К. Липківська (2018), аналізуючи та систематизуючи сучасні найбільш поширені варіанти 
використання новітніх технологій на сцені вітчизняних та зарубіжних театрів, вузькопредметно вивчає, зокрема, експансії мультимедійних технологій. Автор даної публікації широко, в історично-практичному ключі розглядає еволюцію технічних засобів оформлення сценічного простору, при цьому фрагментарно приділяючи увагу його архітектурним характеристикам (Юдова-Романова, 2017). О. Островерх (2007) зосереджує свою дослідницьку увагу на театральному просторі драматичних вистав українського авангарду. Виділення невирішених раніше частин загальної проблеми. Проте у цих та інших наукових уявленнях відсутнє осмислення сценічного оздоблення театрально-видовищних постановок та його просторово-технічної еволюції. Цим i зумовлений вибір теми дослідження: «Дизайн театральної сцени: генезис, історична еволюція, сучасні тенденції».

Мета статті - з'ясування особливостей сценічного дизайну в українському театрі середньовічної епохи.

Виклад основного матеріалу дослідження. Після початку масового хрещення в 988 р. князем Володимиром Русі-України переслідувалось виконання язичницьких обрядів, частина яких зникала, а частина трансформувалась у християнські обряди. Але з релігійними обрядами починає розвиватись світські театралізовані видовища.

У XI ст. 3 розвитком товарно-грошових відносин та занепадом натурального господарства, в процесі якого прогресивні та енергійні селяни у пошуках нової долі мігрують до середньовічних міст. Серед них сюди переїжджають й сільські фіглярі - сільські гострослови, танцюристи, фокусники, блазні, акробати тощо. У результаті суспільного поділу праці народні улюбленці поступово стають професійними потішниками - одночасно лицедіями, музикантами, співаками, лялькарями, танцівниками, гумористами, оповідачами, виконавцями драматичних сценок, акробатами, канатохідцями, фокусниками, виконавцями трюків, зокрема на ходулях, борцями, дресирувальниками диких тварин тощо. Але найголовніше - стають першими в історії театрального мистецтва професійними акторами (Белкін, 1975; Волошин, 1960; Український драматичгий театр. Нариси історії, 1967; Фаминцин, 1889).

У Давній Русі цих авторів, які вели переважно мандрівний спосіб життя, називали скоморохи, у Франції - жонглери, Німеччині - шпильмани, у країнах Середньої Азії довози, масхарабози (Дмитриев, 1967, с. 1023), симдори. Усі ці поняття - практично синонімічні.

Точкою відліку вивчення мистецтва скоморохів, - скористаємось саме цим визначенням давньоруських мандрівних акторів, - стало 9 ст. :саме в 9-10 ст. зображення танцівниць, акробатів, дресирувальників з'являються у пам'ятках історії - у манускриптах, культовій скульптурі. Особливого поширення діяльність мандрівних акторів як популярного мистецтва на території Західної Європи від Середземномор'я до північних рубежів набуває у 11-12 ст., 13-15 ст. - період розквіту скомороства. У великих містах їхня діяльність набуває організованої форми - з'являються корпорації з відповідними статутами. У наслідок такого об'єднання за професійними та територіальними ознаками, наприклад, у Парижі та Кельні 3'являються «вулиці жонглерів», «вулиці музикантів», на яких мешкали представники різних виконавських професій «комедіантів», «скрипалів», «фіделярів» (від «фідель» - струнний смичковий музичний інструмент, один із попередників сімейства віол і скрипок) тощо.

Характерною ознакою виконавського мистецтва скоморохів $\epsilon$ синкретизм нероздільність, злитість, що характерний для будь-якого явища. Історичний поступ синкретичного мистецтва середньовічних акторів згодом призвів до зародження театрального, музичного, хореографічного, циркового мистецтв та мистецтва естради. Натомість нероздільність виконавського мистецтва загалом не виключала певної спеціалізації відповідно до виконавського фаху та аудиторії, перед якою переважно доводилось виступати. При певній універсальності виконавської майстерності хтось ставав фахівцем увиступах з ляльками, хтось із тваринами, хтось у виконанні музичнодраматичних або вокальних творів, хтось мав цирковий хист. Виконавці пісень - трубадури були тісно пов'язані з аристократією та вважали непристойним виконувати акробатичні 
трюки. Загалом репертуар середньовічних мандрівних артистів мав дуже широкий діапазон. Але завжди виконуваним творам притаманні гостра сатира, народний непристойний гумор, а виконавців характеризував високий рівень професійної та фізичної підготовки.

На жаль, загалом відомості про творчість скоморох дуже обмежені, записи зразків репертуару до нас не дійшли. Можна лише зауважити, що характерною рисою творчості як серйозної, так і сміхової було рядження. Манера виконання була переважно імпровізаційнодотепною, виступи відбувалися у постійному спілкуванні з доброзичливою публікою, яка розміщувалася довкола виконавців. Основними жанрами скоморохів-лицедіїв ймовірно були фарси та пародії.

Скоморохи легко перетворювали будь-який публічний простір у сценічний. Головною вимогою до його облаштування було його популярність і легка доступність для потенційних глядачів, - власне, комерційна складова. Тому традиційним сценічним простором для скомороших вистав ставали чи то сільська вулиця, міська базарна площа або заїжджий двір, чи то міст через річку або паперть храму. Натомість для виступів перед заможною публікою міг використовуватись чи то інтер'єр замку, чи зала купецької гільдії. Характерна риса імпровізаційна зручність і жодних підмостків чи завіси. Фактично за відсутності оформлення та за умови використання обмеженого нехитрого реманенту, «вся увага невибагливої публіки концентрувалась на акторові - авторі, виконавцеві та "режисерові” одночасно. Поглинені грою глядачі ставали співучасниками “дійства”» (Даркевич, 2006, с.180).

У Київській Русі наприкінці 10 ст. колишні язичницькі обряди багато в чому втратили своє магічне значення й дедалі частіше перетворювалися на гру-виставу («ігрище», «позорище», «видение»). Цей період характеризується появою на народних святах i гуляннях - ярмарках, весіллях, хрестинах і навіть похоронах - скоморохів. Вони стають не лише безпосередніми учасниками заходів, але й їх організаторами. Окрім участі в народних заходах вони виступали в княжих палатах, навіть проникають у церковну обрядовість.

Саме слово «скоморох» вперше згадується в Лаврентіївському літописі 1068 р. Так називали тих, хто розважав народ, - «потішників», - які не лише співали й танцювали, а й показували дресированих тварин, надягали «личини» й «харі», грали комічні сцени. Однак про скоморохів було відомо й раніше, це засвідчують фрески на сходах у Софії Київській, що їх вчені датують 1037 р. Також про широке побутування скоморохів на території України у 13 - першій половині 17 ст. свідчать згадки про них у «Повісті временних літ», билинний фольклор київського циклу, зображення на пластинчатих браслетах з Києва та інших міст, на срібній чаші з Чернігова (12 ст.), на мініатюрах Радзивіллівського літопису (15 ст.) (Матеріали до історії українського театру. Від витоків до початку ХХ століття, 2016, с. 11).

Судячи зі сходової фрески Софії Київської (рис. 1), вистава у княжому палаці розпочиналася прологом: один скоморох, відкриваючи завісу, звертається до глядачів. У центрі композиції зображені виконавці: по центру внизу двоє танцівників; над ними двоє танцівників-музикантів - один, танцюючи, грає на флейті, другий б'є в тарілки; над ними праворуч - двоє дударів та двоє виконавців на струнних інструментах; праворуч зображена сцена з акробатами: перший тримає жердину, а другий лізе по ній нагору; ліворуч - борці чекають свого виходу. Дослідники стверджують, що це вже може свідчити про існування окремих циркових жанрів (Красовская, 1958, с.14-15). Інша фреска Собору, можливо, відтворює сцену бою «воїна» зі «страховиськом»- один скоморох, одягнутий у шкіру зі звіриною маскою на голові, зображував якусь потвору, а інший - воїна (Проскуряков, 2002, с. 56). 


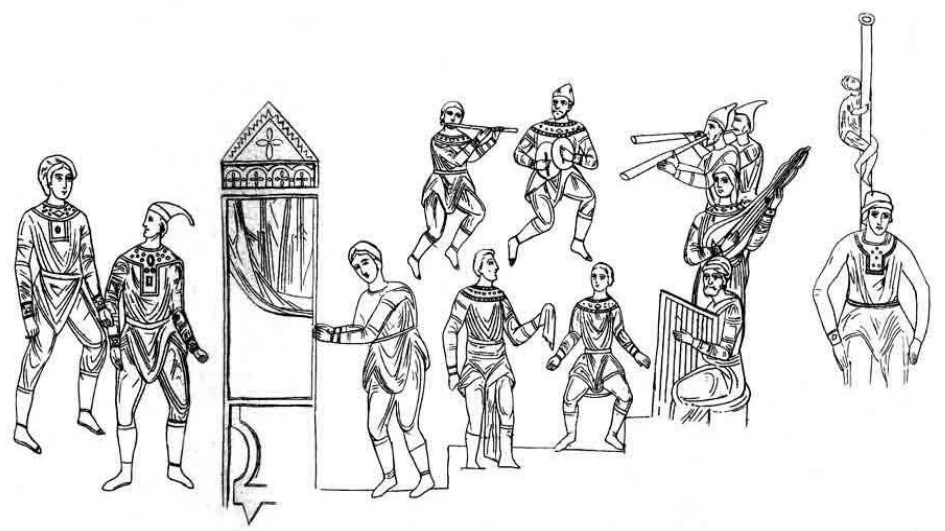

Рисунок 1. Музиканти і скоморохи. Фреска Софійського собору в Києві. Прорисовка В.А. Прохорова. Початок 1870-х pp. (Прохоров, 1872).

Figure 1. Musicians and buffs. Fresco of St. Sophia Cathedral in Kiev. Drawing V.A. Prokhorov The beginning of the 1870's (Prokhorov, 1872).

Щодо організації, то на початку 16 ст. для колективної роботи скоморохи чимдалі активніше стали об’єднуватися в артілі або дружини чи «ватаги». Крім мандрівних скоморохів, були й осілі. Вони переважно виступали на княжих та боярських забавах, весіллях та на ігрищах під час народних масових свят.

Костюм скоморохів, на відміну від блазнів, вирізнявся різноманіттям. Їх упізнавали здалеку за яскравим святковим вбранням, що вирізняло їх з натовпу. Скоморохи носили за поясом різні музичні інструменти, тоненький килимок через плече, кошики з мавпами та різнобарвними папугами, часто водили з собою дресированих ведмедів, коней, собак і кіз. Свропейські скоморохи (гістріони) одягались за модою залежно від достатку від жебрацького лахміття до ошатного вбрання придворних менестрелів. Сукні акторок спадали до п'ят. Заміжні жінки ховали волосся під запиналами та серпанком, дівчата танцювали простоволосими. Перед глядачами 3 оголеним торсом, підперезуючи штани широким ременем виступали артисти циркового спрямування: акробати, приборкувачі диких тварин, борці. У комічних сценах могли надягати маски, розфарбовувати обличчя, використовувати перуки і накладні бороди (Даркевич, 2006, с. 175-176). На фресках Софійського собору в Києві скоморохів зображено у типовому для візантійських мімів одязі- короткопалих каптанах та гостроконечних шапках, - що може свідчити про зображення на фресках виступу іноземних або ж місцевих лицедіїв.

Окрім костюмів мандрівні артисти мали і певний театральний реквізит. Наприклад, лялькар-скоморох мав завісу-спідницю із зашитим у поділ обручем, яку піднімав над головою, а зверху такої імпровізованої фіранки показував свою виставу. Часто скоморохи використовували маски - «скуратов», «личини», «харі», - чіпляли вуса, бороди, вдягали перуки тощо, наряджались у звірині шкури, зокрема, у козу. Музиканти-скоморохи не тільки грали на своїх інструментах - зурнах, домрах, гудках, трубах, гуслах, а й водночас були свого роду читцями-декламаторами усної народної творчості. Циркові фахівці користувалися акробатичним реквізитом, наприклад, ходулями, жердинами. Дресирувальники виступати як iз свійськими тварин, наприклад козою, так і з дикими звірами, зокрема, популярністю користувались ведмеді. Вживаним атрибутом виступів були ширми, за якими виконавці переодягалися та змінювали свою зовнішність.

Народ завжди позитивно сприймав творчість скоморохів за видовищну, привабливість, легкодоступність та демократичність жанру. Їхні виступи не лише сатирично висміювали загальнолюдські вади, але й гостро критикували церковну та світську владу, за що вони піддавались гонінням. Критиці піддавався короткополий одяг, який вважався гріховним, використання масок, 3 якими церква 311 ст. боролась як 3 проявами «москолудства» (рядження) та «бісівська» поведінка. У церковних правилах митрополит Йоанн II в кінці 11 ст. засуджував «плясание, гудение и плескание». Спископ Кирило 
Турівський (XII ст.) забороняв скомороші ігри, пісні, танці, вбачаючи в них гріховні «срамословие, ная словеса и плясание, ежа в пиру и на свадьбах, и в навечерницах, и на игрищах, и на улицах...». Київський митрополит Кирило (XII ст.) вважав злочином «Плясание... и басни бающе», а митрополіт Фотій (1410р.) повчав людей, щоб вони «басней не слушали» (Проскуряков, 2001, с. 59).

Виступаючи проти народного мистецтва скоморохів, в той же час лицедії залишались частиною побуту князівського, а згодом і царського та боярського. До челяді московських царів та бояр іноді належали блазні, «дурні», карлики та інші «потішники». Так, наприклад, у 1571 р. до придворного штату «веселих людей» належали скоморохи, щоб обслуговувати видовища в спеціальній Потішній коморі. На жаль, точних відомостей про характер царських утіх у 16 ст. не збереглося. Мало відомостей про це дає й перша половина 17 ст. Відомо, що через півроку після воцаріння Михайла Романова, в 1613 р., Потішна комора була розширена i замінена Потішною палатою. В історію театру Потішна палата увійшла як перше театральне приміщення в Росії. Скоморохи, відповідно, ввійшли до іiї штату. Як і за часів Київської Русі, пригадаймо вище згадану фреску Софійського собору, придворні виступи мали переважно циркове спрямування. Зауважимо, що діяльність придворних труп не обмежувалася виставами лише «для господарів» - блазні князя Пожарського часто ходили селами «для свого промислу». Одначе коло «придворних» скоморохів у Росії залишалося обмеженим.

Ставлення влади до скоморохів було двояким - сприяючи розвитку їхньої діяльності для царсько-боярської еліти, виступи перед народом заборонялись. Постанова Стоглавого собору 1551 р. зробила скоморохів ізгоями. Царськими указами 1648-го та 1657-го рр. виступи скоморохів було заборонено. Але жодні переслідування влади - ні кара чи шмагання батогами, ні привселюдне спалювання музичних інструментів та реквізиту, ні пізніше заслання на північ не могли змусити цих народних улюбленців кинути своє мистецтво, що продовжувало попри все існувати та розвиватись. У результаті посилення утисків проти скоморохів, на тій частині України, яка приєдналась до складу Російської імперії, скомороство занепадає, а згодом і зникає. Осередком їхньої діяльності стає Правобережна Україна і Галичина. Тут зустрічається багато топонімічних свідчень їхнього існування: Скоморох - мала річка, ліва притока Либеді у Києві; села Скоморохи, Старі Скоморохи, Скоморошки, Скомороше та ін. на Черкащині, Житомирщині, Вінниччині, Тернопільщині, Івано-Франківщині та Львівщині; до 60-70 pp. XX ст. ще існували хутори з аналогічними назвами у зазначених місцевостях та на Волині і Хмельниччині.

У 17-19 ст. діяльність скоморохів поступово перейшла у балагани, де набула подальшого розвитку та стало безпосереднім підгрунтям традицій естрадно-циркового мистецтва. Згодом вони перекваліфіковуються в музикантів i сценічних діячів на західноєвропейський лад. Традиції синкретичного мистецтва скоморохів простежуються у народній культурі України до першої половини 20 ст.

Іншим вектором розвитку сценічного мистецтва епохи Середньовіччя поруч iз мистецтвом мандрівних акторів був церковний театр. В Європі, починаючи з 9 ст., християнська церква, активно протидіючи проявам язичницьких вірувань, починає шукати максимально виразні засоби впливу на вірян. Одним зі шляхів таких проявів став процес театралізації меси. Спочатку виробився культовий ритуал читання в особах біблійних епізодів про життя Христа, зокрема, про його поховання і воскресіння. 3 цих діалогів у виконанні священників у церквах і народжується рання літургійна драма - інсценізація окремих євангельських епізодів і навіть розігрування цілих п’єс на релігійні сюжети.

Після прийняття християнства у Київській Русі також простежується проникнення елементів театру до церковного дійства. Із небагатьох зразків театралізації у візантійському культі в Україні зберігся і проіснував до початку 20 ст. приклад сценічного втілення біблійного епізоду «Умивання ніг», що пов’язувався 3 Великоднем. Зміст дійства грунтувався на євангельському епізоді Тайної вечері, під час якої Христос умивав своїм учням ноги. Сцена розігрувалась посеред храму у Страсний четвер. Головну роль Христа 
виконував архієрей, ролі апостолів - дванадцять, а часом і одинадцять священників, бо ніхто не бажав зображувати Юду Іскаріота. Театралізація епізоду «Умивання Ніг» у православному богослужінні $\epsilon$ свідченням не розкритої до кінця тенденції залучення театральних елементів до культу. Загалом православному (східному) обряду притаманний консерватизм та відсутність суто видовищних елементів, що $є$ характерним приміром для католицького (західного) обряду, та досить довільного прочитання біблійних сюжетів, чим відзначається протестантська церква (Михайлов, 2007, с. 12).

Саме постановки літургійної драми в приміщенні церкви стали першим в історії театрального мистецтва дійством, що відбувалося в закритому просторі. Саме особливості архітектоніки церкви визначали форми сценічного простору, що значною мірою вплинув на архітектуру сучасних театрально-видовищних приміщень. Спершу вся дія драми розвивалася на обмеженій ділянці біля вівтаря. Потім стали використовувати центральний неф, ризницю, притвор, кафедру проповідника. Найважливіші моменти драми розігрувалися на спеціальному помості, що споруджувався всередині будинку.

Церковний театр зробив свій вагомий внесок у розвиток сценографії як мистецтва створення художнього зорового образу сцени засобами декорацій, костюмів, освітлення та іншої постановочної техніки. У цей період був активно запроваджений принцип симультанної декорації, коли всі місця дії показуються одночасно. Апробований ще в античності, принцип попереднього встановлення на ігровій площадці нерухомої декорації у певній послідовності став характерним для європейського середньовічного театру, де спочатку тлом у виставах слугував інтер'єр, а згодом, після винесення дії за межі церкви на паперть - зовнішня стіна церкви. При цьому переміщення виконавця від однісї локації до іншої умовно вказував зміну місця дії. У цей час вже дія драми відбувалась на всій території церкви, для чого використали не лише «корабель»- так в архітектурі називають центральний неф, - а й прилеглі до нього нефи та інші приміщення. У кожному з них розташовувалися декорації відповідних епізодів, що ховались за фіранками. У запланований момент дії шторки розходилися, відкриваючи те або інше місце дії.

Організатори літургійних вистав набували постановочного досвіду, дедалі ширше застосовувались технічні нововведення, приділялася значна увага образотворчим моментам вистави. Предмети церковного ритуалу замінювали спеціально виготовленою бутафорією. Відповідно до потреб сюжетів, виготовлялись воскова фігура дитини у яслах, гробниця, де спочиватиме тіло Христа, квітучі чагарники, яблуні та різні інші предмети реквізиту, необхідного для інсценування біблійних історій про життя, смерть, воскресіння Христа та інших євангельських чудес: мечі, гілки, вінці, квіти й багато іншої атрибутики.

Церковне духовенство прагнуло залучити якнайбільше вірян, тому особливе місце у виставі посідають різні ефекти. Застосовуються механічні звірі та міфічні чудовиська, активно прогресує польотна техніка та широко застосовується ефектне освітлення.

Склеп, що розташовується у підземній частині церкви, як в сучасному театрі iз сценою-коробкою трюм, використовувався для появи персонажів 3-під землі, а також вказував на вхід до пекла. Купол над центральною частиною церковного приміщення слугував для спуску та підйому декоративних конструкцій іноді разом із виконавцями ролей Христа та янголів (рис. 2). Таким чином, церковним театром було закладено трирівневий поділ сценічного простору, що має місце й до сьогодні: нижня сцена, трюм (склеп), власне сцена, iii планшет (рівень підлоги церкви або спеціальний поміст) і верхня сцена, колосникова іiї частина (купол). 


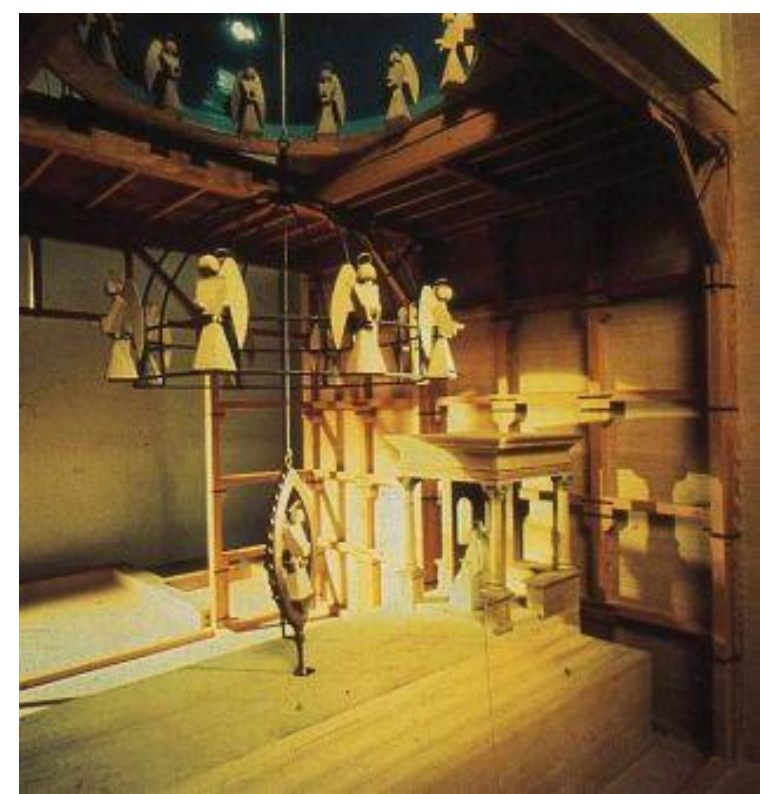

Рисунок 2. Реконструкція в моделі декорацій Ф. Брунеллескі (1377-1446) до вистави «Благовіщеня» у церкві Сан-Феліче-ін-Пяцца (Canticum Salomonis: A Blog for Liturgical Ressourcement).

Figure 2. Reconstruction in the model of scenery by F. Brunelleschi (1377-1446) to the performance of the Annunciation in the church of San Felice in Piazza (Canticum Salomonis: A Blog for Liturgical Ressourcement)

Щоправда, вся техніка, власне - прості мотузки та блоки - хоча й була дещо примітивною, проте справляла надзвичайно видовищне враження на глядачів, які вірили в чудо і приходили до церкви побачити його на власні очі.

Тьмяне природне світло в приміщенні церкви вимагало не лише достатнього штучного освітлення, а й створювало сприятливі умови для розвитку світлових ефектів. У світлі сотень свічок та лампад, що запалювались миттєво одночасно за допомогою своєрідного «бікфордова шнура» і так само затінюючись у потрібний момент спеціальними заслонами, декорації та виконавці не могли залишити нікого байдужим. У цей час, як $\mathrm{i}$ впродовж кількох наступних століть, світлові ефекти створювалися лише із використанням натурального вогню. Ігровий реквізит або фрагменти декорацій з клоччя або соломи, що просочувалась легкозаймистими рідинами, найчастіше спиртом, підпалювались, даючи яскраве і швидке полум'я. Лампади й свічки імітували сяйво зірок, змелена на порошок смола в полум’ї свічі спалахувала іскрами тощо.

Постановочні секрети церковного театру передавалися їх творцями від покоління до покоління, поступово збагачуючись все новими й новими прийомами й новою технікою.

Найрозвиненішим щодо драматичності було так зване Піщне дійство. Виконання чину «Піщного дійства», що розігрувалося незадовго до свята Різдва Христового, зводилося до сценічного відтворення події, розказаної у книзі пророка Даниїла (гл. III): троє єврейських отроків - Ананія, Азарія та Мисаїл, які відмовилися поклонитися кумиру, були кинуті, за наказом царя Навуходоносора, в палаючу піч, але дивним чином вийшли 3 неї неушкодженими. Дійовими особами виступали троє отроків (з хору півчих) і двоє «халдеїв»- виконавці царського наказу, - вдягнуті в особливі костюми. Посеред церкви встановлювали «пещ халдейську» - круглу ширму, прикрашену різьбленням і виточеними фігурами; приносили «горно» 3 гарячим жаром. Під час ранкового богослужіння, після 6-ї пісні канону та отримання належного благословення архієрея, отроків, пов’язаних «убрусцом по виях», передавали халдеям, останні підводили їх до «пещі» і говорили: «Діти цареві, бачте цю піч, вогнем палаючу?..» Отроки відповідали: «Бачимо ми пещ сію, але не жахаємось, є бо Бог наш на небі, Той сильний взяти нас від пещі сієї...» Отрокам давали запалені свічки, і після нового короткого діалогу халдеї вводили їх у пещ. Отроки виконували тут пісню, якій відповідав піснею хор з криласу; халдеї ходили з палаючими свічками кругом пещі й кидали у «горно» легкозаймисту плакун-траву, яка миттю спалахувала. Потім у піч спускали на шнурі гак, на якому зазвичай висить велике панікадило (його заздалегідь знімали) і на 
ньому - пергаментне розфарбоване зображення «Янгола Господнього». Одночасно чувся штучний грім (ударом листа заліза); халдеї падали ниць, зображення янгола знову піднімали вгору, отроки виконували піснеспіви, криласи їм відповідали, i, нарешті, Ананію і товаришів виводили $з$ пещі (Рязанов, 1914, с. 48). (Рис. 3). Зимовий карнавал починався відразу після закінчення храмового дійства. Виконавці халдеїв у дійстві, вийшовши з храму, роздавали на вулицях святочні вогні.

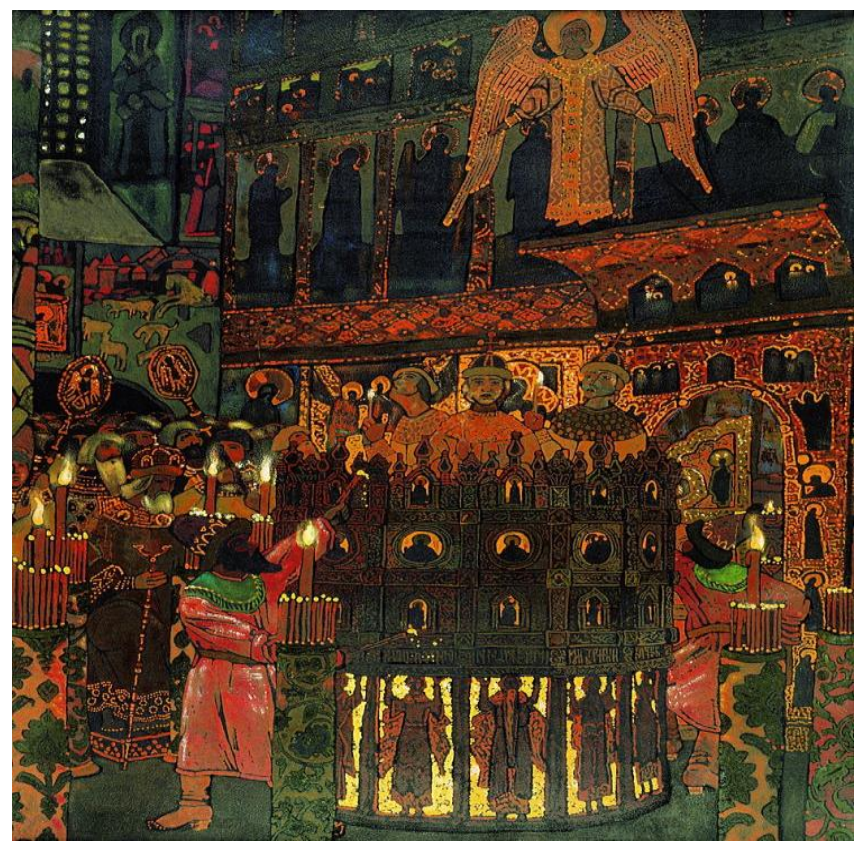

Рисунок 3. М. К. Реріх. Піщне дійство, 1905. Державна Третьяковська галерея. Росія. Москва (Лукашов, 1989). Figure 3. M. K. Roerich. The Pleasant Action, 1905. The State Tretyakov Gallery. Russia. Moscow (Lukashov, 1989).

Середньовічна шкільна драма за своєю змістовно-тематичною та організаційною суттю завжди була тісно пов'язана із церквою. Свідченням цьому $є$ суто релігійне спрямування п’єс, приналежність виконавців до категорії служителів культу - школярів духовних семінарій - та використання приміщення культових споруд для показу вистав. Так, наприклад, 3 тексту інтермедії до драми «Comunia duchowna s.s. Borysa y Hleba», що виконувалась в єзуїтській колегії в кінці 17 ст. у м. Полоцьку, з діалогу героїв стає зрозумілим, що вона мала виконуватись у костьолі, оскільки у ньому згадується костьольний орган (Антонович, 1925, с. 33-34). Неодноразово поряд із використанням приміщення церкви, церковного органу згадуються й інші церковні аксесуари, приміром, плащаниця, які в купі ставали невід'ємною складовою декораційного оформлення сценічного простору вистав шкільного театру.

Ремарки до тексту п’єси «Царства натури людской», виставленої у 1706 р. свідчать про неабиякої складності технічні, звукові та світлові художньо-постановочні ефекти - так, «наприклад у другій сцені першого акту зауважено, що всемогутня рука благословить 3 небес людську натуру; в п’ятій сцені тої ж п’єси сказано, що бог з неба посилає на землю громи і блискавиці, що свідчить про те, що користувалися в постановці світляними ефектами, [...] в третій сцені другого акту бог являється в огняній купині» (Антонович, 1925, с. 35). На жаль, описи генерованих ефектів не містять записів способу їхнього втілення. Такий факт може бути виправданий бажанням постановників зберегти таємниці їхнього втілення, яке пояснюється тим, що з одного боку, економічними причинами, а з іншого - не бажанням церкви допустити в глядачів руйнацію ілюзії дійсного чуда, з вірою в яке вони приходили на вистави до церкви.

Церковний театр проіснував кілька століть. Літургійна драма поступово територіально та організаційно дистанціюючись від церкви і тим самим секуляризуючись та, що важливо, дедалі більше використовуючи постановочні ефекти, до сер. 12 ст. була витіснена 3-під склепінь храмів спочатку на церковний двір. Декораціями до вистав тут стали 
слугувати фасади культових споруд - костьолів, соборів, церков, - на паперті біля яких розігрувалася дія. Указом папи Інокентія III (1210р.) постановки літургійної драми в храмах заборонялися. Згодом 3 паперті церковна, вже так звана напівлітургійна, драма переміщається на вулиці й площі міст. У цей час зароджується новий вид театру - вуличний.

Наукова новизна даної публікації полягає в тому, що вперше виконано системний мистецтвознавчий аналіз поступу просторово-технічного забезпечення вистав українського середньовічного театру в контексті загальноєвропейських процесів. Зокрема, у відповідному художньо-постановочному ключі висвітлено діяльність середньовічних мандрівних артистів та вистави церковного театру.

Висновки. Виходячи з вищезазначеного можна стверджувати:

- середньовічні професійні актори вели переважно мандрівний спосіб життя, що впливало на художньо-постановочні характеристики їхніх мобільних вистав: застосування легких та швидких способів для прилаштування будь-якого публічного простору для виступів артистів з метою отримання оптимальної комерційної вигоди;

- особливості архітектури церкви, де показувались вистави середньовічної літургійної драми, вплинули на умовний тридільний поділ сценічного простору на нижню, основну та верхню сцени, що має місце і в сучасних театрально-концертних приміщеннях;

- церковний театр значно сприяв прогресу у мистецтві створення зорового образу вистави засобами художньо-декораційного оформлення, костюмів, освітлення та іншої постановочної техніки;

- саме у церковному театрі, апробований ще в період античності, був активно запроваджений принцип симультанної декорації;

Художньо-постановочні принципи організації церковного театру в галузі сценічної техніки, освітлення, технологій виготовлення та обслуговування постановочного майна, принципів використання сценічного простору та навички і художні прийоми прилаштовані до мобільного способу організації діяльності мандрівних середньовічних артистів заклали підвалини розвою вуличного містеріального та вертепного театру, що можуть стати предметом подальших досліджень даного темарію. Також запропоновані автором судження та висновки спонукають до подальших мистецтвознавчих досліджень як в напрямку історії та теорії сценічного мистецтва в Україні у контексті світових інтеграційних процесів, так i спонукають до більш глибокого вивчення сучасних мистецьких реалій з огляду набутого історичного досвіду.

\section{Список використаних джерел}

1. Антонович Д. Триста років українського театру. 1619-1919. Прага: Український громадський видавничий фонд, 1925. $271 \mathrm{c.}$

2. Базанов В. В. Технология сиеныл. Москва: Імпульс-свет, 2005. 391 с.

3. Белкин А. А. Русские скоморохи. Москва: Наука, 1975. 190 с.

4. Волошин І. Джерела народного театру на Украӥні. Київ: Держ. вид. образотв. мистецтва і муз. літератури УРСР, 1960. 225 с.

5. Даркевич В. П. Светская праздничная жизнь Средневековья IX-XVI вв. 2-е изд., доп. Москва: Индрик, 2006. 556 с.

6. Дмитриев Ю. А. Эстрада. Театральная энциклопедия. Москва: Советская энциклопедия, 1967. Т. 5. С.1024-1026.

7. Красовская В. М. Русский балетный театр: от возникновения до серединь ХІХ века. Ленинград, Москва: Искусство, 1958. 310 с.

8. Лессинг Г. Э. Гамбургская драматургия. Москва; Ленинград: Academia, 1936. 455 с.

9. Липківська Г. К. Мультимедійні засоби на сучасній театральній сцені. Вісник Київського національного університету культури і мистецтвв. Серія: Сценічне мистецтво. 2018. № 1. C.103-126.

10. Лукашов А. М. Н. Рерих из собрания Государственной Третьяковской галереи. Москва: Изобразительное искусство, 1989. 48 с. 
ISSN 2410-1176 (Print) Вісник КНУКіМ. Серія Мистецтвознавство. Вип. 39. ISSN 2616-4183 (Online)

11. Матеріали до історії украӥнського театру. Від витоків до початку ХХ століття / редкол.: Р. Пилипчук (відповід. ред.) М. Сулима, О. Шевчук, О. Красильникова. Київ: Вид-во ІМФЕ ім. М. Т. Рильського, 2016. 280 с.

12. Михайлов Л. Н. Создание современного эстрадного зрелища (принщипь художественного оформления): дис. ... канд. искусствовед.: 17.00.01. / Рос. Акад. театрального искусства. ГИТИС. Москва, 2007. 124 с.

13. Островерх О. Еволючія просторових систем украйнського драматичного театру: типи організащіi, функиії, людина (від натуралізму до авангарду) : дис. ... канд. мистецтвозн. : 17.00.02 - театральне мистецтво / Ін-т мистецтвознавства, фольклористики та етнології ім. М.Т. Рильського НАН України, 2007. 196 с.

14. Проскуряков В. І. Архітектура украӥнського театру. Простір і дія. Львів: Вид-во нац. ун-ту «Львівська політехніка», 2001. 564 с.

15. Проскуряков В. I. Принциипи розвитку архітектурної типологї̈ украӥнського театру : дис. ... д-ра. архітектури : 18.00 .02 / Нац. ун-т «Львівська політехніка». Львів, $2002.485 \mathrm{c}$.

16. Прохоров В. А. Русские древности издаваемые по Высочайшему соизволению под редакцией В. Прохорова: в 2 т. Санкт-Петербург: Тип. Имп. Акад. наук; Лит. Прохорова, 1872. Т. 1: Материалы по истории русских одежд. Вып. 6. С. 65-74.

17. Рњзанов В. И. Древне-русскія мистеріальныя «дыйства» и школьная драма XVIIXVIII вв. История русскаго театра: Т. 1. Москва: Объединеніе, 1914. С. 25-53.

18. Софронова Л.А. Поэтика славянского театра XVII - первой половины XVIII в.: Польша, Украина, Россия / АН СССР; Ин-т славяноведения и балканистики. Москва: Наука, $1981.264 \mathrm{c}$.

19. Украӥнський драматичний театр. Нариси історї: в 2 т. / за ред.: Ю. Бобошко, М. Йосипенко, П. Нестеровський. Київ: Наукова думка, 1967. Т. 1. 519 с.

20. Фаминцын А. С. Скоморохи на Руси. Санкт-Петербург: Тип. Э. Арнгольда, 1889. 191 с.

21. Френкель М. А. Пластика сценического пространства: некоторые вопросы теории и практики сценографи. Київ : Мистецтво, 1987. 184 с.

22. Юдова-Романова К. В. Технічні засоби оформлення сценічного простору. Київ: Вид. центр КНУКіМ, 2017. 314 с.

23. Whatever Happened to French Rood Screens? Fr. Thiers' Dissertation Ecclésiastique sur les Jubés. Canticum Salomonis: A Blog for Liturgical Ressourcement. URL: https://sicutincensum.wordpress.com/tag/ambo/ (accessed: 30.11.2018).

\section{References}

1. Antonovych, D. (1925). Trysta rokiv ukrainskoho teatru. 1619-1919 [Three hundred years of Ukrainian theater. 1619-1919]. Prague: Ukrainskyi hromadskyi vydavnychyi fond.

2. Bazanov, V.V. (2005). Tekhnologiya stseny [Technology scenes]. Moscow: Impul's-svet.

3. Belkin, A.A. (1975). Russkie skomorokhi [Russian Medieval Entertainers]. Moscow: Nauka.

4. Boboshko, Yu., Yosypenko, M. and Nesterovskyi P. eds. (1967). Ukrainskyi dramatychnyi teatr. Narysy istorii: v 2 t. [Ukrainian Drama Theater. Essays on history]. In 2 vols. Vol. 1. Kyiv: Naukova dumka.

5. Darkevich, V.P. (2006). Svetskaya prazdnichnaya zhizn'Srednevekov'ya IX-XVI vv. [Secular festive life of the Middle Ages of the 9th - 16th centuries]. 2nd ed., Moscow: Indrik.

6. Dmitriev, Yu.A. (1967). Estrada [Pop-art]. Teatral'naya entsiklopediya, Vol. 5, pp.1024-1026.

7. Famintsyn, A.S. (1889). Skomorokhi na Rusi [Medieval Entertainers in Russia]. St. Petersburg: Tipografiya E. Arngol'da.

8. Frenkel', M.A. (1987). Plastika stsenicheskogo prostranstva: nekotorye voprosy teorii $i$ praktiki stsenografi [Plastics of the stage space: some issues of the theory and practice of scenographers]. Kyiv: Mistetstvo. 
9. Krasovskaya, V.M. (1958). Russkii baletnyi teatr: ot vozniknoveniya do serediny XIX $v e k a$ [Russian ballet theater: from the appearance to the middle of the XIX century]. Leningrad, Moscow: Iskusstvo.

10. Lessing, G.E (1936). Gamburgskaya dramaturgiya [Hamburg drama]. Moscow; Leningrad: Academia.

11. Lypkivska, H.K. (2018). Multymediini zasoby na suchasnii teatralnii stseni [Multimedia on the modern theater scene]. Visnyk Kyivskoho natsionalnoho universytetu kultury $i$ mystetstv. Seriia: Stsenichne mystetstvo, no.1. pp.103-126.

12. Lukashov, A.M. (1989). N. Rerikh iz sobraniya Gosudarstvennoi Tret'yakovskoi galerei [N. Roerich from the collection of the State Tretyakov Gallery]. Moscow: Izobrazitel'noe iskusstvo.

13. Mikhailov, L.N. (2007). Sozdanie sovremennogo estradnogo zrelishcha (printsipy khudozhestvennogo oformleniya) [Creation of a modern pop show (principles of decorating)]. Candidate's thesis. Russian Academy of Theatre Arts -GITIS.

14. Ostroverkh, O. (2007). Evoliutsiia prostorovykh system ukrainskoho dramatychnoho teatru: typy orhanizatsii, funktsii, liudyna (vid naturalizmu do avanhardu) [Evolution of the openspace systems of the Ukrainian dramatic theater: the types of organizations, functions, people (from naturalism to the avant-garde)] Candidate's thesis. M. Rylsky Institute of Art, Folklore Studies and Ethnography of the Academy of Sciences of Ukraine.

15. Proskuriakov, V.I. (2001). Arkhitektura ukrainskoho teatru. Prostir i diia. [Architecture of the Ukrainian Theater. Space and action]. Lviv: The publishing house of the National University "Lviv Polytechnic".

16. Proskuriakov, V.I. (2002). Pryntsypy rozvytku arkhitekturnoi typolohii ukrainskoho teatru [Principles of development of the architectural typology of the Ukrainian theater]. Doctor's thesis. National University "Lviv Polytechnic".

17. Prokhorov, V.A. (1872). Russkie drevnosti izdavaemye po Vysochaishemu soizvoleniyu pod redaktsiei $V$. Prokhorova [Russian antiquities, published according to the highest permission, edited by V. Prokhorov]. in 2 vols. Vol. 1: Materialy po istorii russkikh odezhd. Sankt-Peterburg: Tipografiya Imperatorskoi Akademii nauk; Litografiya Prokhorova,

18. Pylypchuk, R., Sulyma, M., Shevchuk, O. and Krasylnykova, O. eds. (2016). Materialy do istorii ukrainskoho teatru. Vid vytokiv do pochatku XX stolittia [Materials for the history of the Ukrainian theater. From the origins to the beginning of the twentieth century]. Kyiv: Vydavnytstvo Instytutu mystetstvoznavstva, folklorystyky ta etnolohii im. M. T. Rylskoho

19. Ryazanov, V.I. (1914). Drevne-russkiya misterial'nyya «deistva» i shkol'naya drama XVII-XVIII vv. [Old Russian mystery "actions" and school drama of the XVII-XVIII centuries]. Istoriya russkago teatra: T. 1. Moscow: Ob"edinenie, pp. 25-53.

20. Sofronova, L.A. (1981). Poetika slavyanskogo teatra XVII - pervoi poloviny XVIII v.: Pol'sha, Ukraina, Rossiya [Poetics of the Slavic Theater XVII - the first half of the XVIII century: Poland, Ukraine, Russia]. Moscow: Nauka.

21. Voloshyn, I. (1960). Dzherela narodnoho teatru na Ukraini [Sources of folk theater in Ukraine]. Kyiv: Derzhavne vydavnytstvo obrazotvorchoho mystetstva i muzychnoi literatury URSR.

22. Iudova-Romanova, K.V. (2017). Tekhnichni zasoby oformlennia stsenichnoho prostoru [Technical means of designing the stage space]. Kyiv: Vydavnychyi tsentr Kyivskoho natsionalnoho universytetu kultury i mystetstv.

23. Whatever Happened to French Rood Screens? Fr. Thiers' Dissertation Ecclésiastique sur les Jubés. Canticum Salomonis: A Blog for Liturgical Ressourcement. Available at: <https://sicutincensum.wordpress.com/tag/ambo/> [Accessed 30.11.2018].

(C) Юдова-Романова К. В., 2018 